\title{
N87 $=29925$
}

DEVELOPHENT OF AMBIENT TEMPERATURE SECONDARY LITHIUM CELLS

\author{
S. Subbarao, D.H. Shen, S. Dawson, F. Deligiannis, \\ J. Taraszkiewicz, and G. Halpert \\ Jet Propulsion Laboratory \\ California Institute of Technology \\ Pasadena, California 91109
}

Under a NASA-OAST sponsored program, JPL is developing ambient temperature secondary lithium cells for future spácećraft applications. Priór studies on experimental laboratory type $\mathrm{Li}_{-} \mathrm{TiS}_{2}$ cells yielded promising results in terms of cycle life and rate capability. To further assess the performance of this cell, $5 \mathrm{Ah}$ engineering model cells were developed. Initially baseline cells were designed and fabricated. Each cell had 15 cathodes and 16 anodes and the ratio of anode to cathode capacity is 6:1. A solution of 1.5 molar LiAsF 6 in $2 \mathrm{Me}-\mathrm{THF}$ was used as the electrolyte. Cells were evaluated for their cycle life at $\mathrm{C} / 2$ and C/5 discharge rates and 100 percent depth of discharge. The cells were cycled between voltage limits 1.7 and 2.8 volts. The rate of charge in all cases is $\mathrm{C} / 10$. The results obtained indicate that cells can operate at $\mathrm{C} / 10$ to $\mathrm{C} / 2$ discharge rates and have an initial energy density of $70 \mathrm{Wh} / \mathrm{kg}$. Cells delivered more than 100 cycles at $\mathrm{C} / 2$ discharge rate. This paper describes the details of cell design, the test program, and the results obtained.

\section{INTRODUCTION}

Under a NASA OAST sponsored program, Jet Propulsion Laboratory is developing ambient temperature secondary lithium batteries for future space applications. These lithium batteries have a number of intrinsic and potential advantages such as higher energy density, longer active shelf life, lower self discharge etc. over conventional $\mathrm{Ni}-\mathrm{Cd}, \mathrm{Pb}$-acid and $\mathrm{Ag}-\mathrm{Zn}$ batteries. The main objective of the program is to demonstrate the feasibility of developing cells with greater than $100 \mathrm{Wh} / \mathrm{kg}$ specific energy while delivering 1,000 cycles at moderate depths of discharge (60-70\%). The program pay-offs are 2-3 fold increase in energy storage capability and a longer active shelf life over $\mathrm{Ni}-\mathrm{Cd}$ and $\mathrm{Ni}-\mathrm{H}_{2}$. Some of the projected applications of these batteries are for Mars Rover, planetary space craft/probes, astronaut equipment, and GEO spacecraft. To achieve these ambitious goals, we have examined the performance potential of $\mathrm{Li}_{-} \mathrm{TiS}_{2}, \mathrm{Li}_{-} \mathrm{MOS}_{3}$ and $\mathrm{Li}-\mathrm{V}_{6} \mathrm{O}_{13}$ systems in detail. Among these three, the $\mathrm{Li}-\mathrm{TiS}_{2}$ system has shown the longest cycle life and highest rate capability. Experimental five cell $\mathrm{Li}^{-T i S}{ }_{2}$ batteries $(10.5 \mathrm{~V}, 0.4 \mathrm{Ah})$, developed in-house, have completed twelve simulated and accelerated GEO seasons successfully (1). These encouraging results prompted us to assess the performance capability of the $\mathrm{Li}^{-\mathrm{TiS}_{2}}$ system in engineering model $5 \mathrm{Ah}$ cells. This study will serve as an intermediate step before 
building prototype flight 20-35Ah cells. Development of $5 \mathrm{Ah}$ cells is proposed to be completed by 1989 . In this paper we report the results of our preliminary work done on the development of baseline SOA $5 \mathrm{Ah}$ cells.

\section{CELL DESIGN}

The computer program, developed earlier (2) for the design trade-off studies of $35 \mathrm{Ah} \mathrm{Li-TiS} 2$ cells was used in the selection of a design for the $5 \mathrm{Ah}$ baseline engineering model cells. Some of the important design features of the cell are given in Table 1 . The $\mathrm{TiS}_{2}$ cathode is the limiting electrode and ratio of anode to cathode capacity is 6:1. This high anode to cathode capacity was chosen to accommodate the degradation of $\mathrm{Li}$ electrode and achieve maximum cycle life. Results of the design trade-off analysis indicate that the capacity ratio has minimal effect on specific energy of the cells (Table 1). The operating current density of the cell at $\mathrm{C} / 2$ discharge rate was $2 \mathrm{~mA} / \mathrm{cm}^{2}$. Operation at current densities higher than $2 \mathrm{~mA} / \mathrm{cm}^{2}$ is limited by the poor conductivity of the electrolyte. The cell contains $15 \mathrm{TiS}_{2}$ cathodes and $16 \mathrm{Li}$ anodes Celgard 2400 , a porous polypropylene film, was chosen as the separator material. The composition of the electrolyte is $1.5 \mathrm{M} \mathrm{LiAsF} 6 / 2 \mathrm{Me}-\mathrm{THF}$ and each cell is activated with $40 \mathrm{cc}$ of electrolyte. This electrolyte quantity is designed to fill the internal void volume of the electrodes, and separator, and other minor cell void spaces. The cell weighs approximately $230 \mathrm{grams}$, and the weight budget is given in Figure 1. It may be noted that the cell can is the major contributor to cell weight. Among the active materials, $\mathrm{Li}$ contributes the least to the overall weight. The collector grids contribute more to the weight than does lithium alone. The use of titanium cases and aluminum grids will reduce cell weight considerably.

\section{TIS2 CATHODE DEVELOPMENT}

The suitability of various processing methods such as brushing, pressing, and rolling have been examined in the fabrication of $\mathrm{TiS}_{2}$ cathodes with EPDM binder. The brushing method even though simple, was not found suitable for making large electrodes. Considerable problems were encountered in making electrodes by the pressing method due to poor flow characteristics of the electrode active material. The rolling method on the other hand, offered many advantages such as amenability to scale-up, uniform loading, incorporation of integral tabs, etc.

The $\mathrm{TiS}_{2}$ electrodes required for $5 \mathrm{Ah}$ baseline cells were fabricated by the rolling method and the details of processing are given in Figure 2. TiS 2 , the active material of the cathodes, was processed in-house by a vapor transport method involving a chemical reaction between titanium and sulphur. This material had a stoichiometry of $\mathrm{T}_{1 \pm 0.1} \mathrm{~S}_{2}$. The approximate composition of electrode material is $86 \% \mathrm{TiS}_{2}, 10 \%$ conducting diluent and $4 \%$ binder. Shawinigan black was chosen as the conducting diluent in view of it's chain-like structure, high conductivity and purity (3). EPDM was used as the binder material. The binder was dissolved in cyclohexane (1\%) and added to $\mathrm{TiS}_{2}$ and carbon mix. Excess solvent was removed by vacuum extraction. The resulting material was ground to a fine powder and applied onto a nickel exmet screen by rolling. Electrode active material preparation was carried out in an argon atmosphere chamber. The electrode processing was done in a dry room (humidity less that $0.5 \%$ ). 
Master electrodes $\left(6^{\prime \prime} \times 6^{\prime \prime} \times 0.02^{\prime \prime}\right)$ were fabricated and cut into required dimensions. The porosity of the electrodes is about 35 to $40 \%$ and the active material loading is $75 \pm 5 \mathrm{mg} / \mathrm{cm}^{2}$. The surface area of the electrodes is about $12 \mathrm{M}^{2} / \mathrm{gm}$. These electrodes have exhibited more than $90 \%$ faradic utilization initially in experimental cells $(150 \mathrm{mAh})$ and yielded more than 200 cycles (100\% DOD) with only $20 \%$ loss in capacity.

\section{RESULTS AND DISCUSSION}

Baseline engineering model cells were evaluated for their charge/discharge characteristics, rate capability, and cycle life. Cells were charged by constant current method at $\mathrm{C} / 10$ rate to $2.7 \mathrm{~V}$. Cells were discharged at different rates to a cutoff voltage of $1.7 \mathrm{~V}$. Charge discharge characteristics of the cell at $\mathrm{C} / 10$ rate are given in Figure 3. The cell exhibits sloping charge/discharge curves which are typical for the intercalation cathodes Discharge characteristics of the cell at $\mathrm{C} / 10, \mathrm{C} / 5$, and $\mathrm{C} / 2$ rates are given in Figure 4 . At the $\mathrm{C} / 10$ rate cells delivered approximately $7.8 \mathrm{Ah}$ which is roughly equivalent to $100 \%$ capacity. Energy density of the cells at this rate is found to be about $75 \mathrm{wh} / \mathrm{kg}$. At C/2 discharge rate, cells have exhibited approximately a capacity of $6 \mathrm{Ah}$. Cells were evaluated for their cycle life characteristics at $\mathrm{C} / 5$ \& $\mathrm{C} / 2$ discharge rates to $100 \%$ DOD. The capacity of the cells as a function of cycle number is given in Figure 5. The cells were found to lose capacity upon cycling. The impedance of cells was also found to increase on cycling. The cells cycling at $\mathrm{C} / 2$ lost approximately $0.05 \mathrm{Ah} / \mathrm{cycle}$ and by the end of $100 \mathrm{th}$ cycle cells delivered only about $3 \mathrm{Ah}$. Surprisingly the cells cycling at $\mathrm{C} / 5$ discharge rate failed at about 60 cycles. Probably, the cells developed "soft-shorts" as revealed by longer charge periods. Similar problems were encountered (soft shorts) while testing commercial secondary $\mathrm{Li}$ cells at low discharge rates (4). The low cycle life performance of the $5 \mathrm{Ah}$ baseline cells may be due to electrolyte degradation, starved electrolyte condition, processing of cells in the dry room, non-optimized cell design, or charge methodology. We are in the process of evaluating and optimizing these parameters. Cells with optimized design will be built and tested for their performance and safety and we are anticipating to complete this work by the end of 1989 .

\section{FUTURE DIRECTIONS}

A number of areas are under investigation to improve the energy density and the cycle life performance of secondary Li cells. Some of the major areas are high energy density cathode materials, high performance electrode structures, stable electrolytes, design optimization, and improved charge methodology. Among various cathode materials, $\mathrm{NbSe}_{3}$ appears promising and its performance potential is being assessed in experimental cells. The limited cycle life capability of rechargeable lithium cells is mainly due to the high reactivity of lithium with the electrolyte. A number of mixed solvent electrolytes are currently being evaluated for conductivity, viscosity, stability towards lithium and lithium cycling efficiency. Pulse charging and modified constant current charging methods will be examined to improve cell performance. We are planning to complete these activities by 1992 and build prototype cells for flight qualification.

\section{ACKNOWLEDGEMENTS}

This work represents one phase of research performed by the Jet Propulsion Laboratory, California Institute of Technology sponsored bv the National Aeronautics and Space Administration under contract NAS-7-918. 


\section{REFERENCES}

1 B. Otzinger, 1984 GSFC Battery Workshop, NASA Conference Publication 2382, 1985, pg. 95.

2 D.H. Shen, S. Subbarao, S.P.S. Yen and R.B. Somoano, Journal of Power Sources, 18 (1986) 127-131.

3 D.H. Shen, S. Subbarao, S.P.S. Yen, B.J. Carter and R.B. Somoano, ECS Extended A bstracts, 84-2, 1984, p8.190.

\begin{tabular}{cc} 
TABLE I. - INFLUENCE OF ELECTRODE CAPACITY RATIO ON SPECIFIC ENERGY \\
\hline $\begin{array}{c}\text { ANODE TO CATHODE } \\
\text { CAPACITY RATIO }\end{array}$ & $\begin{array}{c}\text { SPECIFIC ENERGY } \\
\text { (Wh/Kg) }\end{array}$ \\
5.5 & 58.2 \\
5.0 & 58.4 \\
4.0 & 58.8 \\
3.0 & 59.3 \\
2.0 & 59.8 \\
1.0 & 60.3
\end{tabular}


ORIGIS:

OF FOCR Qunilir

TABLE II. - OUTLINE OF 5-Ah Li-TiS 2 GELL DESIGN

1) THEO. ANODE CAPACITY (Ah) $=38.5$

2) THEO. CATHODE CAPACITY (Ah) $=6.6$

3) ELECTRODE CAPACITY RATIO $=5.8: 1$

4) NO OF ANODES $\left(2.75^{\prime \prime} * 2.5^{\prime \prime} * .014^{\prime \prime}\right)=15$

5) NO OF CATHODES $\left(2.75^{\prime \prime} * 2.5^{\prime \prime} * .025^{\prime \prime}\right)=14$

6) CURRENT DENSITY $(\mathrm{mA} / \mathrm{cm} 2)=2.0$

7) ELECTROLYTE (1.5M LIAsF6/2Me-THF) $=40$

8) CELL WEIGHT (g) $=230$

9) CELL DIMENSIONS (in) $=2.78 * 4 * 98$

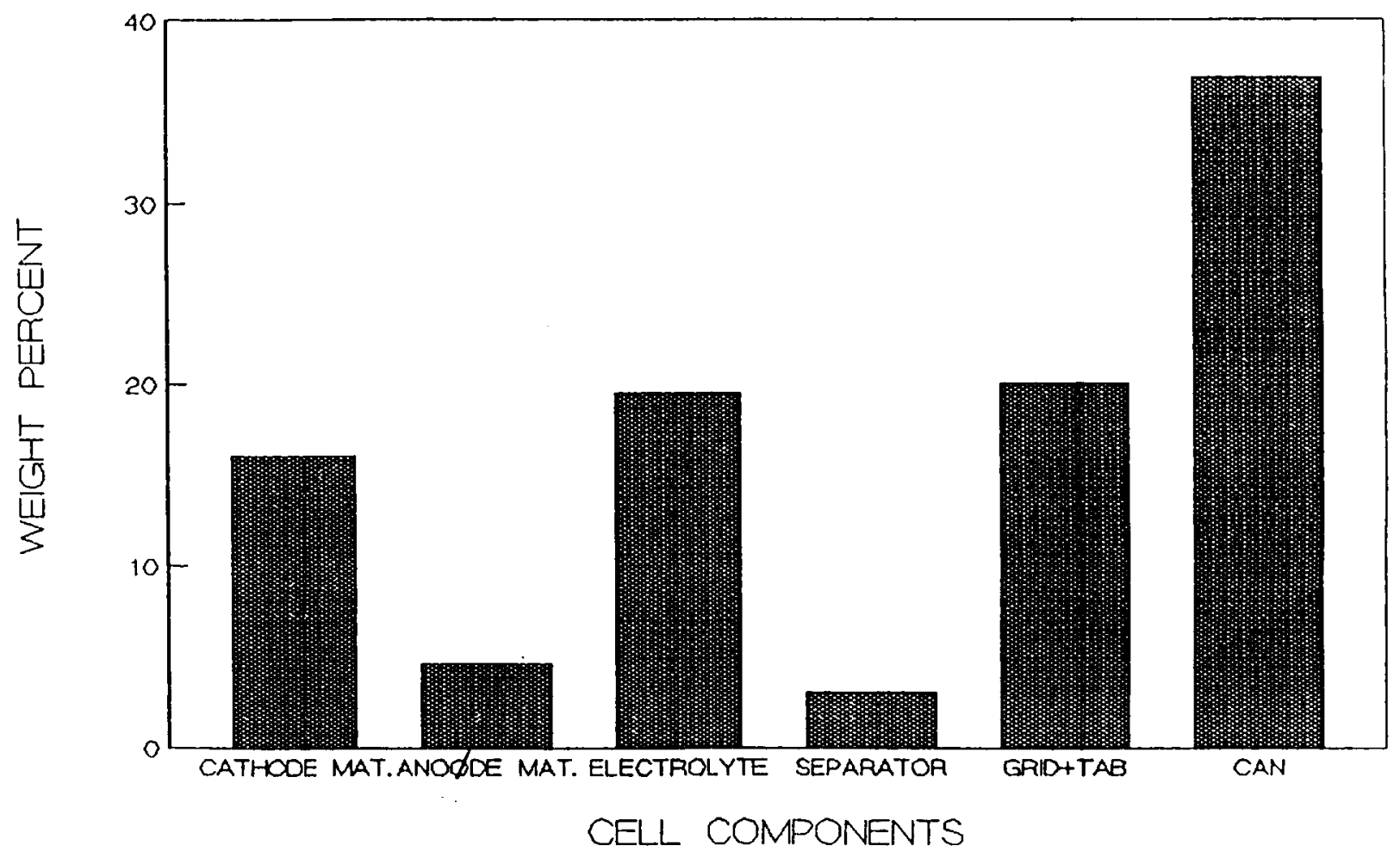

Figure 1. - 5-Ah Li-TiS 2 cell weight budget. 


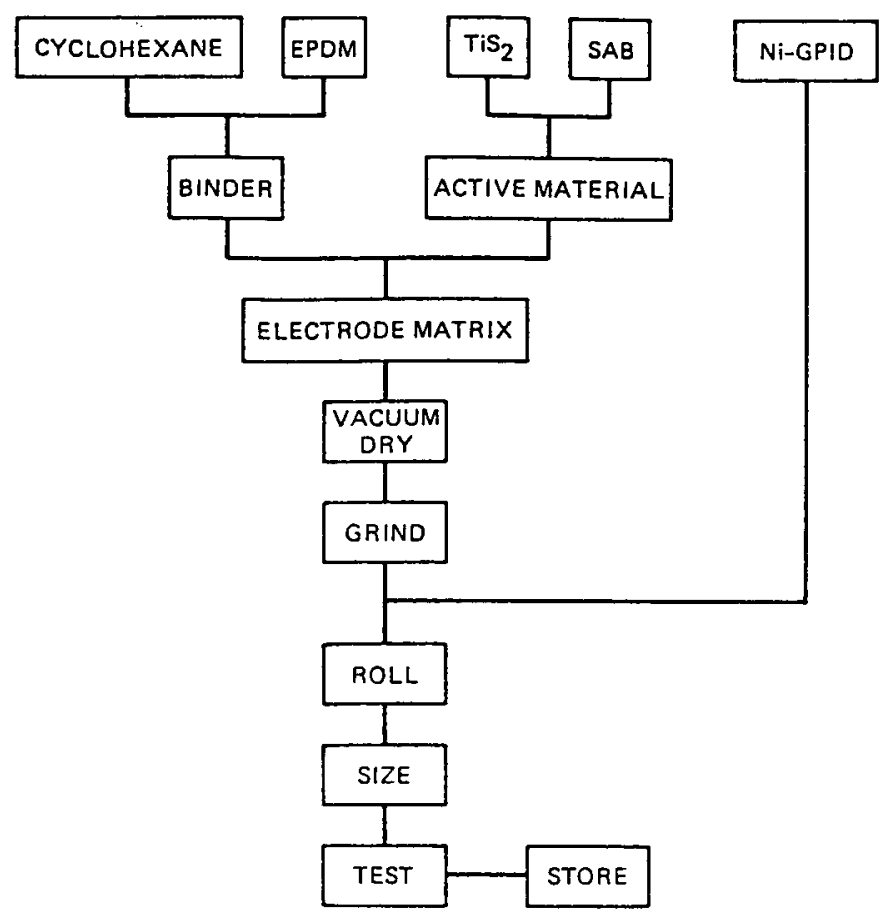

Figure 2. - Tis 2 electrode process.

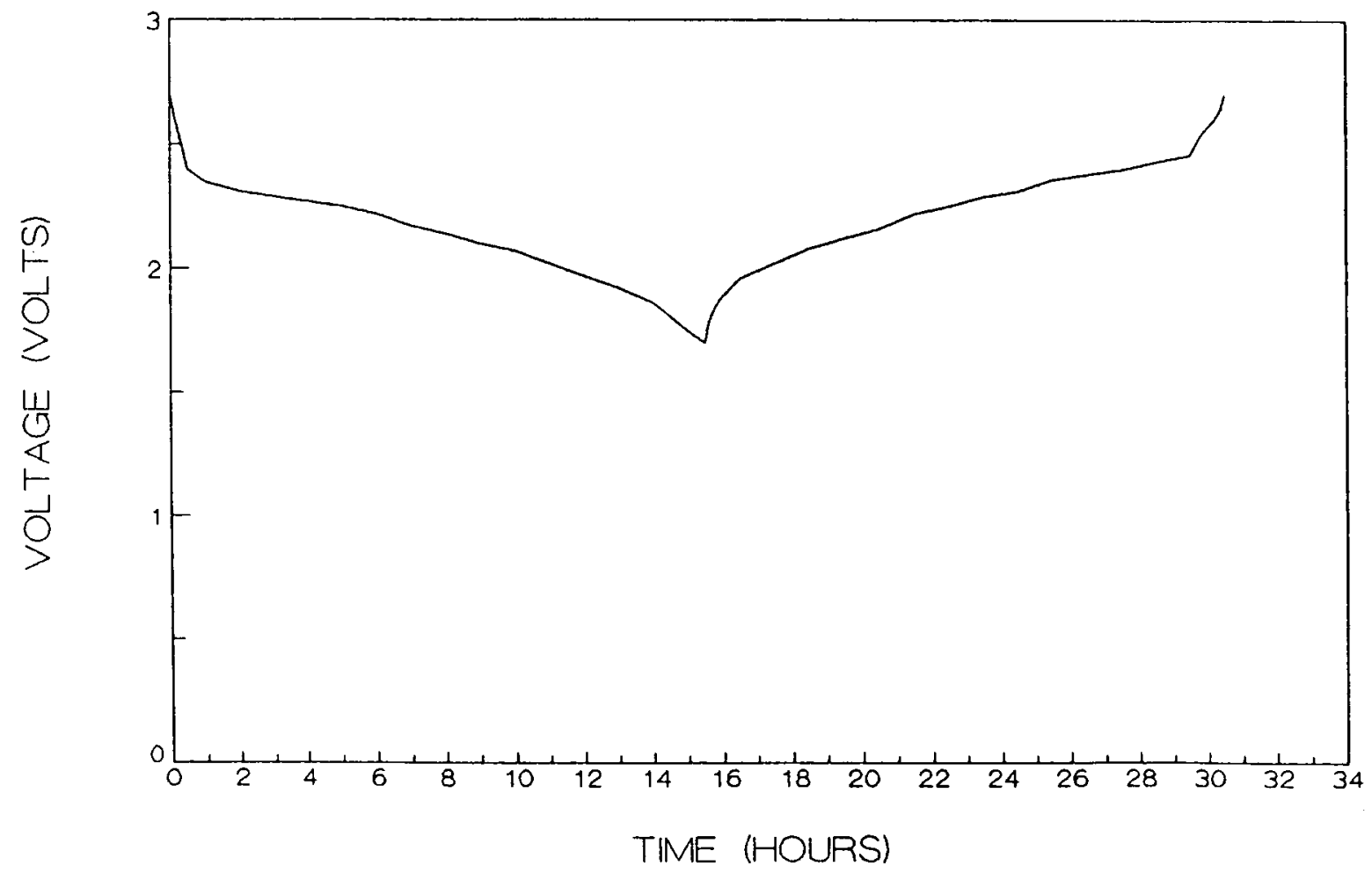

Figure 3. - Discharge and charge characteristics of 5-Ah Li-Tis 2 cells. 


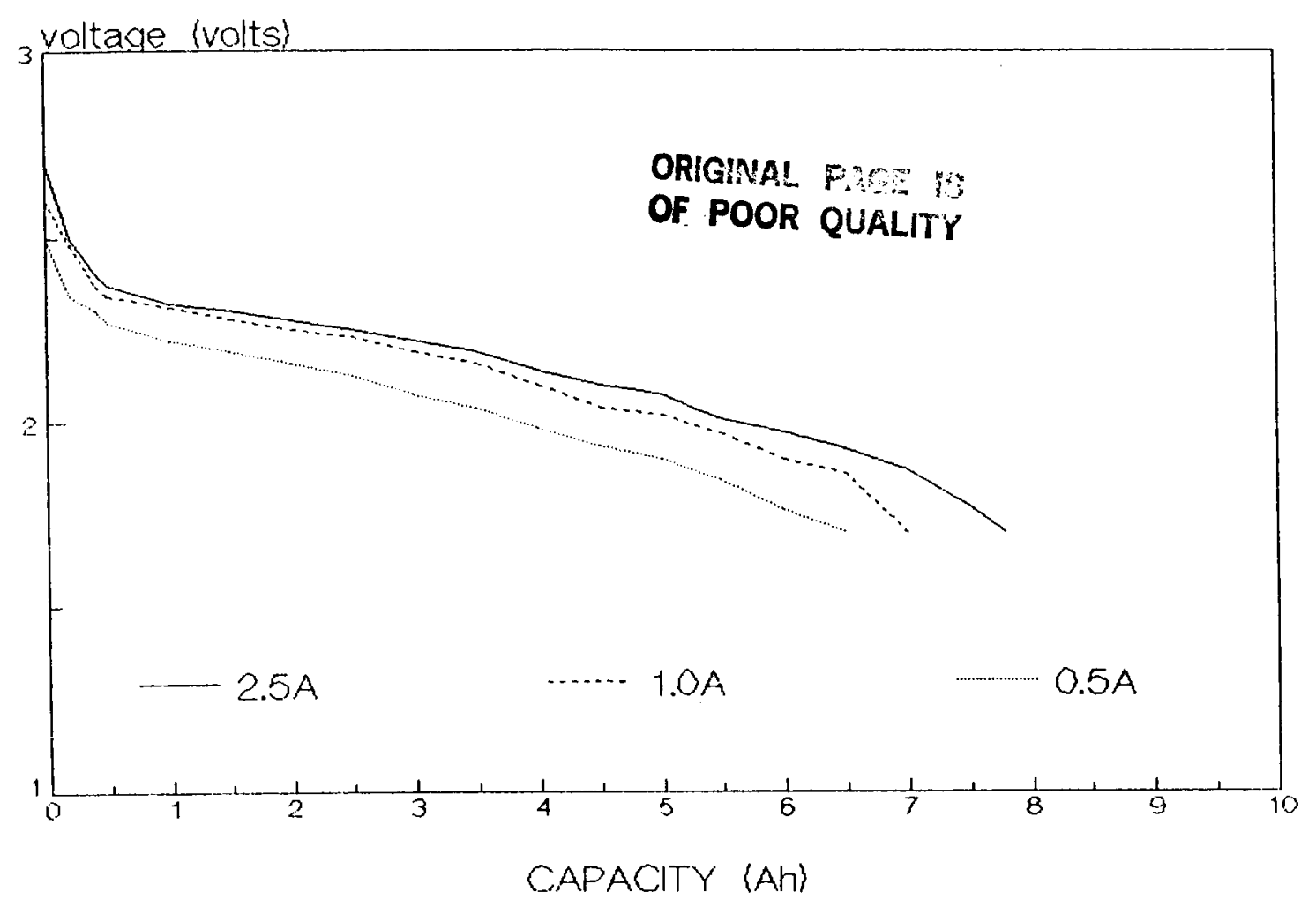

Figure 4. - Discharge characteristics of 5-Ah Li-Tis 2 cells.

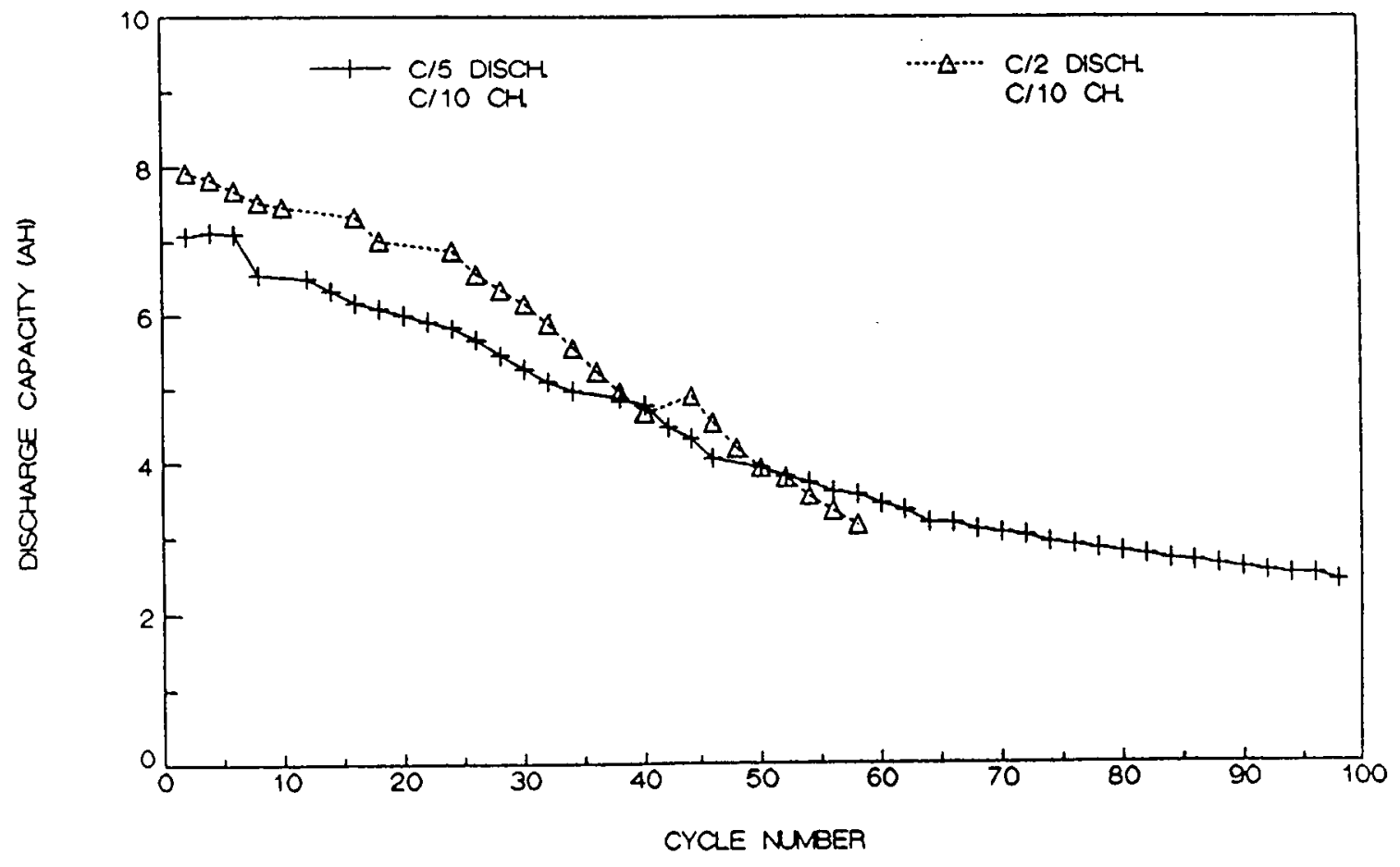

Figure 5. - Cycling characteristics of JPL 5-Ah Li-TiS 2 cells. 